\title{
SUPERVISI KEPALA SEKOLAH TERHADAP GURU MATA PELAJARAN UJIAN NASIONAL DI SMPN 2 RAMBATAN
}

\author{
Zulhadi \\ Kepala SMPN 1 Batipuah \\ Korespondensi: Simpang Congkong, Kec. Batipuh, Kab. Tanah Datar, Sumatera Barat \\ e-mail: zulhadi.72@gmail.com
}

\begin{abstract}
The problem of this research is "Supervision of Principal to the National Examination Subject Teachers in SMP N 2 Rambatan". And the purpose of this recearch is to describe How Supervision of Principal to the National Examination Subject Teachers in SMP N 2 Rambatan. This research is a qualitative case study method. The main instrument of this research is the researcher bimself, and the supporting instruments are a tape recorder, interview guides and other documents. To obtain the required data, the researcher used techniques include observation, documentation and the principal interviews national examination subject teachers. The results of the research based on observation, interviews and documentation, the researcher can take some conclusions as follows: (1) Planning of supervision programs of principal to develop the competence of the National Examination Subject Teacher in order to get the maximum result, (2) Implementation of supervision programs of principal to develop the competence of the National Examination Subject Teacher in order to get the maximum result, (3) Evaluation and follow-up supervision programs of principal to develop the competence of the National Examination Subject Teacher in order to get the maximum result. Based on how the overall Supervision of Principal to the national examination subject teachers is not maximized. This is evident from the evaluation and follow-up of the supervision itself did not cover all aspects of supervision.
\end{abstract}

Keywords: Supervision, Headmaster, Teachers

\section{PENDAHULAN}

Pengawasan (supervisi) dalam suatu kegiatan atau lembaga sangat diperlukan guna untuk mengetahui kekuatan atau kelemahan dari kegiatan atau lembaga tersebut sebagai bahan evaluasi. Lembaga pendidikan atau kegiatan akademik perlu di awasi proses berjalan kegiatan di dalamnya, apakah suadah sesuai secara prosedural atau secara teknis pelaksanaannya. Supervisi Akademik adalah serangkaian kegiatan membantu guru mengembangkan kemampuannya mengelola proses pembelajaran untuk mencapai tujuan pembelajaran. Supervisi akademik tidak terlepas dari penilaian kinerja guru dalam mengelola pembelajaran. Sergiovanni (1982) menegaskan bahwa refleksi praktis penilaian kinerja guru dalam supervisi akademik adalah 
melihat kondisi nyata kinerja guru untuk menjawab pertanyaan-pertanyaan, misalnya apa yang sebenarnya terjadi di dalam kelas?, apa yang sebenarnya dilakukan oleh guru dan siswa di dalam kelas?, aktivitas-aktivitas mana dari keseluruhan aktivitas di dalam kelas itu yang bermakna bagi guru dan murid?, apa yang telah dilakukan oleh guru dalam mencapai tujuan akademik?, apa kelebihan dan kekurangan guru dan bagaimana cara mengembangkannya?. Berdasarkan jawaban terhadap pertanyaan-pertanyaan ini akan diperoleh informasi mengenai kemampuan guru dalam mengelola pembelajaran. Namun satu hal yang perlu ditegaskan di sini, bahwa setelah melakukan penilaian kinerja berarti selesailah pelaksanaan supervisi akademik, melainkan harus dilanjutkan dengan tindak lanjutnya berupa pembuatan program supervisi akademik dan melaksanakannya dengan sebaik-baiknya.

Lazaruth (1994) mengemukakan salah satu tugas kepala sekolah adalah sebagai supervisor yaitu pembina dan pembimbing guru agar bekerja dengan betul dalam proses pembelajaran siswanya. Supervisi pembelajaran mempunyai tiga prinsip yaitu: (a) supervisi pembelajaran langsung mempengaruhi dan mengembangkan perilaku guru dalam mengelola proses belajar mengajar; (b) perilaku supervisor dalam membantu guru mengembangkan kemampuannya harus didesain dengan jelas; (c) tujuan supervisi pembelajaran adalah guru makin mampu menjadi fasilitator dalam belajar bagi siswanya.

Penelitian ini dilatarbelakangi oleh belum optimalnya supervisi kepala sekolah SMPN 2 Rambatan Kenagarian Simawang, hal ini berdasarkan data yang diperoleh ketika penulis melakukan observasi sebagai berikut:

a) Tahun 2012 juara 1 lomba sekolah sehat (LSS) tingkat Kabupaten Tanah Datar (SK Bupati Tanah Datar)

b) Tahun 2012 juara 1 lomba sekolah adiwiyata tingkat Kabupaten Tanah Datar (SK Bupati Tanah Datar)

c) Tahun 2013 juara 2 lomba sekolah sehat tingkat provinsi (SK gubernur Sumatra Barat)

d) Tahun 2013 kategori pertama sekolah adiwiyata tingkat nasional, sekarang membina 13 sekolah baik SMP maupun SD yang ada di kabupaten Tanah Datar untuk menjadi sekolah adiwiyata, hal ini sebagai langkah bagi untuk maju sekolah adiwiyata tigkat Asean. (SK Gubernur Sumatra Barat dan dari Kementrian Lingkungan Hidup)

e) Tahun 2015 sekarang, sekolah kembali mewakili sekolah yang ada di Kabupaten Tanah Datar dalam rangka lomba sekolah sehat (LSS) tingkat provinsi

f) Tahun 2015 juga SMPN 2 Rambatan maju sebagai sekolah adiwiyata mandiri tingkat nasional dan membina 13 sekolah yang ada di Kabupaten Tanah Datar untuk lanjut ke tinggkat Asia Tenggara.

Namun prestasi itu semua berbanding terbalik dengan mutu pendidikan yang ada di sekolah. Pada tahun 2014 sekolah ini berada pada posisi 34 dan pada tahun 2015 berada pada posisi 49 dari 53 SMP di Kabupaten Tanah Datar dalam hasil ujian nasional. Berdasarkan data dokumentasi yang penulis lakukan, penulis menemukan nilai siswa yang telah lulus, baik tahun ajaran 2013-2014 maupun 2014-2015, 
khusus pada mata pelajaran yang di ujian nasional mendapatkan nilai dibawah 3.00, seperti mata pelajaran matematika dan mata pelajaran IPA dan yang mendapatkan nilai tersebut bukan hanya dua atau tiga orang saja namum rata-rata $40 \%$ dari siswa tersebut yang mendapatkan nilai dibawah 3.00. Hal ini menjadi salah satu faktor penghambat bagi siswa untuk melanjutkan pendidikan ke sekolah unggulan yang ada di dalam mapun di luar Kabupaten. Berdasarkan data yang penulis dapat pada tahun 2013, siswa yang ingin melanjutkan ke SMAN 3 Batusangkar hanya satu orang yang diterima dari 10 siswa orang yang mendaftar, selain itu siswa yang mendaftar ke SMAN 1 Sumatera Barat yang merupakan sekolah unggulan di tingkat provinsi namun tidak satupun yang lolos seleksi PMB.

\section{PEMBAHASAN}

\section{Supervisi Pendidikan}

Supervisor adalah seorang yang profesional. Dalam menjalankan tugasnya, ia bertindak atas dasar kaidah-kaidah ilmiah untuk meningkatkan mutu pendidikan. Untuk melakukan supervisi diperlukan kelebihan yang dapat melihat dengan tajam terhadap permasalahan peningkatan mutu pendidikan, menggunakan kepekaan untuk memahaminya dan tidak hanya sekedar menggunakan penglihatan mata biasa. Ia membina peningkatan mutu akademik melalui penciptaan situasi belajar yang lebih baik, baik dalam hal fisik maupun lingkungan non fisik.

Pengertian supervisi secara etimologis menurut Poerwadarminto (1976), menye- butkan bahwa dilihat dari bentuk perkataannya, supervisi terdiri dari dua buah kata super + vision: Super = atas, lebih, Vision = lihat, tilik, awasi. Makna yang terkandung dari pengertian tersebut, bahwa seorang supervisor mempunyai kedudukan atau posisi lebih dari orang yang disupervisi, tugasnya adalah melihat, menilik atau mengawasi orang-orang yang disupervisi.

Supervisi merupakan bentuk pembinaan yang berupa bimbingan atau tuntutan ke arah perbaikan, supervisi merupakan pengawasan profesional, sebab hal ini di samping bersifat lebih spesifik juga melakukan pengamatan terhadap kegiatan akademik yang mendasarkan pada kemampuan ilmiah, dan pendekatannya pun bukan lagi pengawasan manajemen biasa, tetapi lebih bersifat menuntut kemampuan profesional yang demokratis dan humanistik oleh para pengawas pendidikan.

Supervisi pada dasarnya diarahkan pada dua aspek, yakni: supervisi akademis, dan supervisi manajerial. Supervisi akademis menitikberatkan pada pengamatan supervisor terhadap kegiatan akademis, berupa pembelajaran baik di dalam maupun di luar kelas. Supervisi manajerial menitik beratkan pada pengamatan pada aspek-aspek pengelolaan dan administrasi sekolah yang berfungsi sebagai pendukung (supporting) terlaksananya pembelajaran.

\section{Kepala Sekolah}

\section{Pengertian Kepala Sekolah}

Secara etimologi kepala sekolah adalah guru yang memimpin sekolah. (W.J.S. Poerwadarminto, 1976). Berarti secara terminology kepala sekolah dapat diartikan sebagai tenaga fungsional guru 
yang diberikan tugas tambahan untuk memimpin suatu sekolah di mana diselenggarakan proses belajar mengajar atau tempat di mana terjadi interaksi antara guru yang memberi pelajaran dan murid yang menerima pelajaran.

Kepala Sekolah adalah pimpinan tertinggi di sekolah. Pola kepemimpinannya akan sangat berpengaruh bahkan sangat menentukan kemajuan sekolah. Oleh karena itu dalam pendidikan modern kepemimpinan kepala sekolah merupakan jabatan strategis dalam mencapai tujuan pendidikan.

\section{Fungsi Kepala Sekolah}

Kepala sekolah adalah pemimpin tertinggi di sekolah. Pola kepemimpinanya akan sangat berpengaruh bahkan sangat menentukan kemajuan sekolah. Oleh karena itu dalam pendidikan modren, kepemimpinan seorang kepala sekolah harus mampu menjalankan fungsi sebagai kepala sekolah yang merupakan jabatan strategis dalam pencapaian tujuan sekolah.Menurut Mulyasa (2007) kepala sekolah mempunyai 7 fungsi utama yaitu; Kepala Sekolah Sebagai Educator (Pendidik), Kepala Sekolah Sebagai Manajer, Kepala Sekolah Sebagai Administrator, Kepala Sekolah Sebagai Supervisor, Kepala Sekolah Sebagai Leader (Pemimpin), Kepala Sekolah Sebagai Inovator, Kepala Sekolah Sebagai Motivator.

Dalam hal memajukan pendidikan seorang kepala sekolah harus mementingkan sikap kepedulian terhadap apa yang dipimpinya sehingga memberikan dampak yang progresif dalam pengembangan sekolah. Kepala sekolah dalam meningkatkan mutu pendidikan memerlukan kepandaian dalam mengidentifikasi serta mampu merumuskan hasil kerja yang ingin dicapai oleh sekolah. Kemudian seorang Kepala Sekolah juga harus bisa mengorganisasikan pekerjaannya yang mencakup pemberian dan pembagian tugas dan wewenang kepada guru maupun staf, serta melaksanakan supervisi kemudian berusaha mampu mewujudkan rencana yang dibuat sekolah.

\section{Peran dan Tugas Tanggung Jawab Kepala Sekolah}

Menurut Purwanto (2002), bahwa seorang kepala sekolah mempunyai sepuluh macam peranan, yaitu: "Sebagai pelaksana, perencana, seorang ahli, mengawasi hubungan antara anggota-anggota, menwakili kelompok, bertindak sebagai pemberi ganjaran, bertindak sebagai wasit, pemegang tanggung jawab, sebagai seorang pencipta, dan sebagai seorang ayah.

Kepala sekolah bertanggung jawab atas manajemen pendidikan secara mikro, yang secara langsung berkaitan dengan proses pembelajaran disekolah. Sebagaimana dikemukakan dalam pasal 12 ayat 1 PP 28 Th. 1990 bahwa kepala sekolah bertanggung jawab atas penyelenggaraan kegiatan pendidikan, administrasi sekolah, pembinaan tenaga kependidikan lainnya, dan pendayagunan serta pemeliharaaan sarana dan prasarana. (Mulyasa, 2007). Menurut Dirawat, tugas dan tanggungjawab kepala sekolah dapat digolongkan kepada dua bidang, yaitu: (Dirawat, dkk, 1986) Tugas kepala sekolah dalam bidang administrasi dapat digolongkan menjadi enam bidang yaitu:

1. Pengelolaan pengajaran

2. Pengelolaan kepegawaian

3. Pengelolaan kemuridan 
4. Pengelolaan gedung dan halaman

5. Pengelolaan keuangan

6. Pengelolaan hubungan sekolah dan masyarakat

Tugas kepala sekolah dalam bidang administrasi dapat digolongkan menjadi empat bidang yaitu:

1. Membimbing guru-guru agar mereka dapat memahami secara jelas tujuantujuan pendidikan pengajaran yang hendak dicapai dan hubungan antara aktivitas pengajaran dengan tujuantujuan.

2. Membimbing guru-guru agar mereka dapat memahami lebih jelas tentang persoalan-persoalan dan kebutuhan murid.

3. Menyeleksi dan memberikan tugas-tugas yang paling cocok bagi setiap guru sesuai dengan minat, kemampuan bakat masing-masing dan selanjutnya mendorong mereka untuk terus mengembangkan minat, bakat dan kemampuannya.

4. Memberikan penilaian terhadap prestasi kerja sekolah berdasarkan standarstandar sejauh mana tujuan sekolah itu telah dicapai.

\section{METODE PENELTIAN}

Jenis penelitian mengunakan pendekatan kualitatif dengan mengunakan metode studi kasus, Studi kasus adalah suatu penelitian yang dilakukan secara intensif, terinci dan mendalam terhadap suatu organisasi, lembaga atau gejala tertentu. Menurut Creswell, (2007) Kasus itu sendiri adalah sesuatu yang dipandang sebagai sesuatu sistem kesatuan yang menyeluruh, tetapi terbatasi oleh kerangka konteks tertentu. Sebuah kasus adalah isu atau masalah yang harus dipelajari, yang akan mengungkapkan pemahaman yang mendalam tentang kasus tersebut. Melalui penelitian studi kasus, kasus dapat dijelaskan secara terperinci dan komprehensif.

Dalam mengumpulkan data yang dibutuhkan, peneliti menggunakan teknik pengumpulan data wawancara, observasi, dan dokumen. Kegiatan wawancara dan observasi dilakukan untuk mengetahui kegiatan dan kejadian sesngguhnya tentang pelaksanaan supervisi kepala sekolah terhadap guru mata pelajaran ujian nasional. Studi dokumen yang dilakukan menyangkut pelaksanaan supervisi kepala sekolah terhadap guru mata pelajaran ujian nasional. Sedangkan analisis data dilakukan melalui 3 tahap yaitu data reduction (Reduksi Data); data dispaly (Penyajian Data); dan Conclusion drawing verivication (kesimpulan). Dalam menguji keabsahan peneliti mengunakan triangulasi data, seperti yang dikemukakan oleh Sugiyono (2008) yang terdiri dari empat macam triangulasi diantaranya Data triangulation (peneliti menguji keabsahan data), Investigator triangulation (pengujian data), Theory triangulation (analisis data) Methodological triangulation (pengujian data).

\section{HASIL PENEUTIANDAN PEMBAHASAN}

a. Perencanaan Supervisi Kepala Sekolah Untuk Pengembangan Kompetensi Guru Mata Pelajaran Ujian Nasional Dalam Rangka Meningkatkan Hasil Belajar Siswa 
Berdasarkan temuan penelitian melalui Wawancara dan Observasi terhadap guru mata pelajaran ujian nasional didalam Perencanaan Program supervisi Kepala Sekolah Untuk Mengembangkan Kompetensi Guru Mata Pelajaran Ujian Nasional dalam Rangka Meningkatkan Hasil Belajar Siswa sudah berjalan dengan baik sesuai dengan konsep supervisi itu sendiri hal ini terlihat dari adanya bentuk upaya komonikasi yang baik dari kepala sekolah dalam rangka perencanaan supervisi akademik. Kemudian beliau juga membahas secara bersama dengan guru lain persoalan kapan waktu dan prosesnya seperti apa, kemudian guru juga di tugaskan untuk mempersiapkan bahan-bahan yang akan di nilai ketika di dalam kelas nanti

Kepala sekolah merupakan ujung tombak dari keberhasilan sebuah sekolah meskipun di sekolah tersebut terdapat guruguru yang berkompeten namun apabila kepala sekolah tidak profesional maka sulit untuk sebuah sekolah tersebut maju kedepannya, namun meskipun di sekolah tersebut terdapat guru yang tidak berkompoten namun kepala sekolahnya profesional maka kemungkinan sekolah tersebut bisa lebih maju kedepannya. Karena salah satu tugas dari kepala sekolah adalah melakukan supervisi akademik, Supervisi akademik adalah serangkaian kegiatan membantu guru mengembangkan kemampuannya mengelola proses pembelajaran untuk mencapai tujuan pembelajaran. Supervisi akademik tidak terlepas dari penilaian kinerja guru dalam mengelola pembelajaran. Sergiovanni (1987) menegaskan bahwa refleksi praktis penilaian kinerja guru dalam supervisi akademik adalah melihat kondisi nyata kinerja guru untuk menjawab pertanyaan-pertanyaan, misalnya apa yang sebenarnya terjadi di dalam kelas?, apa yang sebenarnya dilakukan oleh guru dan siswa di dalam kelas?, aktivitas-aktivitas mana dari keseluruhan aktivitas di dalam kelas itu yang bermakna bagi guru dan murid?, apa yang telah dilakukan oleh guru dalam mencapai tujuan akademik?, apa kelebihan dan kekurangan guru dan bagaimana cara mengembangkannya?. Berdasarkan jawaban terhadap pertanyaanpertanyaan ini akan diperoleh informasi mengenai kemampuan guru dalam mengelola pembelajaran. Namun satu hal yang perlu ditegaskan di sini, bahwa setelah melakukan penilaian kinerja berarti selesailah pelaksanaan supervisi akademik, melainkan harus dilanjutkan dengan tindak lanjutnya berupa pembuatan program supervisi akademik dan melaksanakannya dengan sebaik-baiknya.

Dari penjelasan kepala sekolah diatas dapat penulis simpulkan bahwa supervisi itu bertujuan untuk menilai kinerja guru ketika proses pembelajaran sedang berlangsung, karena kepala sekolah akan melihat langsung apa yang dilakukan oleh guru dan siswanya didalam kelas ketika proses pembelajaran berlangsung. Dengan tujuan bukan untuk mencari kelemahan guru melainkan untuk memberikan bantuan atau solusi bagi guru ketika guru tersebut kesulitan dalam melaksanakan proses pembelajaran.

b. Pelaksanaan Program supervisi Kepala Sekolah untuk Mengembangkan Kompetensi Guru Mata Pelajaran Ujian Nasional dalam Rangka Meningkatkan Hasil Belajar Siswa.

\section{2 | Jurnal al-Fikrah, Vol. VI, No. 2 Juli-Desember 2018}


Bedasarkan hasil wawancara dan observasi dapat penulis simpulkan bahwa pelaksanaan program supervisi kepala sekolah untuk mengembangkan kompetensi guru mata pelajaran ujian nasional dalam rangka meningkatkan hasil belajar siswa sudah berjalan dengan baik hal ini terlihat dari metode yang diterapkan oleh kepala sekolah ketika melakukan supervisi akademik. Kepala sekolah dalam melakukan supervisi bukan hanya dengan metode kunjungan kelas saja melainkan menggunakan bermacam variasi dari metode supervisi yang ada kemudian beliau melakukan dengan penuh profesional meskipun yang disupervisi itu adalah guru senior atau orang yang paling dekat dengan beliau.

Konsep dan tujuan supervisi akademik, sebagaimana dikemukakan oleh para pakar supervisi akademik di muka, memang tampak idealis bagi para praktisi supervisi akademik (kepala sekolah). Namun, memang demikianlah seharusnya kenyataan normatif konsep dasarnya. Para kepala sekolah baik suka maupun tidak suka harus siap menghadapi problema dan kendala dalam melaksanakan supervisi akademik. Adanya problema dan kendala tersebut sedikit banyak bisa diatasi apabila dalam pelaksanaan supervisi akademik kepala sekolah menerapkan prinsip-prinsip supervisi akademik.

Dari penjelasan diatas dapat penulis simpulkan bahwa pelaksanaan program supervisi kepala sekolah untuk pengembangan kompetensi guru dalam rangka peningkatan hasil belajar siswa sudah terlaksana dengan baik. Kesemua itu terlihat dari pelaksanaan supervisi akademik yang dilakukan oleh kepala sekolah mencakup semua kompetensi yang dimiliki oleh guru, seperti kompetensi padagogik, profesional, personal dan sosial.

c. Evaluasi dan tindak lanjut Program supervisi Kepala Sekolah untuk Mengembangkan Kompetensi Guru Mata Pelajaran Ujian Nasional Dalam Rangka Meningkatkan Hasil Belajar Siswa.

Hasil dari supervisi perlu dievaluasi dan ditindak lanjuti agar memberikan dampak yang nyata untuk meningkatkan profesionalisme guru. Dampak nyata ini diharapkan dapat dirasakan oleh siswa maupun stakeholders. Evaluasi tersebut berupa penguatan dan penghargaan yang diberikan kepada guru yang telah memenuhi standar, supaya guru tersebut semakin termotivasi lagi untuk lebih baik kedepannya dan sebuah teguran yang sifatnya mendidik diberikan kepada guru yang belum memenuhi standar sehingga guru tersebut diberikan kesempatan untuk mengikuti pelatihan atau penataran lebih lanjut supaya lebih baik lagi kedepannya.

Dari penjelasan di atas dapat penulis simpulkan bahwa evaluasi dan tindak lanjut yang dilakukan oleh kepala sekolah setelah melakukan supervisi itu sudah terlaksana namun ada beberapa kekurangan dari kepala sekolah dari beberapa guru diatas. Kepala sekolah sebagai supervisor hanya memberikan atau solusi saja tampa ada aplikasinya dan tindak lanjutnya kedepan. Misalnya, kepala sekolah melakukan supervisi kemudian beliau menemukan adanya guru yang tidak bisa menggunakan media teknologi seperti infokus. Seharusnya 
untuk menghemat anggaran biaya kepala sekolah bisa mengadakan pelatihan tentang penggunaan media, begitu juga dengan penggunaan media komputer khusunya power point dalam proses pembelajaran

Dari penjelasan di atas, dapat penulis simpulkan bahwa evaluasi dan tindak lanjut yang dilakukan oleh kepala sekolah tidak berkelanjutan dan evaluasi dan tidak lanjut yang dilakukan tidak mencakup keseluruhnya hanya sebatas supervisi kunjungan kelas saja. Meskipun kepala sekolah melakukan pertemuan kelompok, individu, dan observasi kelas. Kepala sekolah ketika mengevaluasi supervisi akademik tidak terfokus kepada bagaimana keadaan guru ketika hendak melaksanakan PBM saja. Sehingga pada akhirnya tujuan dari supervisi itu sendiri adalah untuk pengembangan kompetensi guru agar bisa tercapai seperti kompetensi pedagogik, sosial, personal dan profesional.

Pembinaan yang dilakukan oleh kepala sekolah juga tidak jelas, kepala sekolah melakukan pembinaan hanya sebatas lisan saja, tidak ada bukti tertulisnya (buku pembinaan guru). Setelah satu minggu melaksanakan supervisi kepala sekolah memanggil guru yang bersangkutan kemudian guru tersebut disampaikan kelemahannya dimana dan kepala sekolah cuman memberikan arahan secara lisan saja tentang perbaikan kedepannya.

Kompetensi supervisi akademik intinya adalah membina guru dalam meningkatkan mutu proses pembelajaran. Sasaran supervisi akademik adalah guru dalam melaksanakan proses pembelajaran, yang terdiri dari materi pokok dalam proses pembelajaran, penyusunan silabus dan RPP, pemilihan strategi/metode/teknik pembelajaran, penggunaan media dan teknologi informasi dalam pembelajaran, menilai proses dan hasil pembelajaran serta penelitian tindakan kelas.

\section{PENUTU}

\section{Kesimpulan}

Bedasarkan hasil penelitian tentang Supervisi Kepala Sekolah Terhadap Guru di SMPN 2 Rambatan dapat peneliti ambil beberapa kesimpulan sebagai berikut

1) Perencanaan program supervisi yang dilakukan oleh kepala sekolah untuk pengembangan kompetensi guru mata pelajaran yang diujian nasionalkan dalam rangka peningkatan hasil belajar siswa sudah berjalan sesuai dengan ketentuannya.

2) Pelaksanaan program supervisi yang dilakukan oleh kepala sekolah untuk pengembangan kompetensi guru mata mata pelajaran yang diujian nasionalkan dalam rangka peningkatan hasil belajar siswa sudah berjalan sesuai dengan ketentuannya.

3) Evaluasi dan tindak lanjut program supervisi yang dilakukan oleh kepala sekolah untuk pengembangan kompetensi guru mata pelajaran yang diujian nasionalkan dalam rangka peningkatan hasil belajar siswa belum berjalan sesuai dengan ketentuannya.

Secara keseluruhan tentang bagaimana supervisi kepala sekolah dalam rangka meningkatkan kopetensi guru mata pelajaran ujian nasional belum berjalan sesuai 
dengan ketentuannya, hal ini terlihat dari evaluasi atau tindak lanjut dari supervisi itu sendiri tidak mencakup semua aspek dari supervisi itu sendiri. Sebagus apapun suatu perencanaan dan pelaksanaan dari perencanaan tersebut tampa adanya evaluasi yang matang maka maka perencanaan dan pelaksanaan yang bagus tadi akan menjadi sia-sia,karna evaluasi dan tindak lanjut dari evaluasi akan membawa dampak yang baik kedepannya.

\section{Saran}

1. Untuk kepala sekolah harus benar-benar melakukan supervisi itu sesuai dengan pentunjuk-petunjuknya supaya bisa membawa dampak yang positif terhadap guru yang disupervisi.

2. Bagi kepala sekolah dalam melakukan supervise untuk mengembangkan kompetensi guru harus mencakup semua aspek dari kompetensi yang dimilki oleh guru itu sendiri.

3. Bagi guru tetap pertahankan loyalitas terhadap tugas dan tanggung jawab sebagai pendidik dan loyalitasa terhadap kepala sekolah meskipun kepala sekolah tidak seperti yangkita harapkan.

4. Bagi guru kedisplinan, tanggung jawab, kebersamaan dan rasa saling memiliki yang sudah terbangun jangan samapai hilang meskipun terjadi permasalahan antara guru dengan kepala sekolah,dan guru sesama guru

5. Bagi siswa SMPN 2 Rambatan selalulah berbuat kebaikan untuk sekolah, tetap pertahankan nilai-nilai kepedulian terhadap sekolah yang sudah tertanam meskipun suatu saat tidak berada di SMPN 2 Rambatan lagi.

\section{KEPUSTAKAANACUAN}

Creswell, Jhon w. (2007) Qualitative Inquiry \& Research Design, Choosing Among Five Approach. California: Sage Publications.

Lazaruth, Soewadji. 1994. Kepala Sekolah dan Tanggung Jawabnya. Yogyakarta: Kanisius.

Lexy J. Moleong. 2005. Metodelogi Penelitian Kualitatif. Bandung: Remaja Rosdakarya.

M. Arifin. 1993. Filsafat Pendidikan Islam. Jakarta: Bumi Aksara.

Mattew B Milles.A Michael Huberman, 2007, Analisis Data Kualitatif, UI Pres.

Mills, L.R. Gay, Geoffrey E. \& Airasian, 2009, Educational Research: Competencies for analysis and application-9 $9^{\text {th }}$. Ed, (New Jersey: Merril-Pearson Education).

Mulyasa. 2007. Menjadi Kepala Sekolah Profesional. Bandung: PT Remaja Rosdia Karya.

Muslich, Masnur. 2007. Sertifikasi Guru Menuju Professionalisme Pendidik. Jakarta: Bumi Aksara.

Purwanto, Ngalim.2002. Administrasi Dan Supervisi Pendidikan. Bandung: PT. Remaja Rosdakarya.

Sergiovanni. 1982. Supervision Of Teaching. Alexandria: Association For Supervision and Curriculum Development. 
Sugiyono, 2008, Memahami Penelitian W.J.S. Poerwadarminto, 1976, Kamus Umum Kualitatif, Bandung, Alfabeta.

Wahjosumidjo, 2011, Kepemimpinan Kepala Bahasa Indonesia, Jakarta: Balai Pustaka.

Sekolah, Jakarta: PT Raja Grafindo Persada.

146 | Jurnal al-Fikrah, Vol. VI, No. 2 Juli-Desember 2018 